\title{
Effects of Using Digital Devices on Food Consumption among University Students in Nepal
}

\section{Dirgha Raj Joshi}

Mahendra Ratna Campus Tahachal, Tribhuvan University, Nepal and Nepal Open University Email:dirgha@nou.edu.np

\section{Umesh Neupane}

Email: umesh.neupane@bumc.tu.edu.np

Butwal Multiple Campus, Tribhuvan University, Butwal, Nepal

\section{Jitendra Kumar Singh}

Email: jsingdj@gmail.com

Department of Community Medicine, Janaki Medical College, Tribhuvan University, Janakpur, Nepal

\section{Bishnu Khanal}

Email: bkhana11974@gmail.com

Mahendra Ratna Campus Tahachal, Tribhuvan University Nepal

\section{Shashidhar Belbase}

Email: sbelbase@uaeu.ac.ae

College of Education, United Arab Emirates University, Al Ain, UAE

\section{Corresponding author:}

\section{Dirgha Raj Joshi}

Email:dirgha@nou.edu.np

DOI: https://doi.org/ 10.3126/irjmmc.v2i4.41552

Received: December 1, 2021; Revised \& Accepted: December 9, 2021; Published: December 22,2021

(C) Copyright: joshi (2021).

\section{ABSTRACT}

Food consuming behavior is a concern for good physiological, physical, psychological, and social health. An unbalanced eating habit may be related to several factors. The objective of the study was to investigate how the use of digital devices influences graduate students' eating behavior. A cross-sectional study was conducted among 320 Masters of Philosophy (MPhil) scholars of Nepal Open University through an online survey. A Chi-square test and a binary logistic regression model were fitted to find the effect of digital devices on food consumption. There was a significant association between the duration of using a mobile phone, computer, and TV with the quantity of food consumed, preferred time of using a laptop with the quantity of food consumed, and the sitting position during the use of digital devices with the quantity of food consumed. The logistic regression model showed that individual's sitting positions while using digital devices were significant predictors of food consumption at a 95\% confidence level.

Keywords: Computer, digital devices, food consumption, laptop, mobile, TV 


\section{INTRODUCTION}

Technological devices and tools profoundly impact people's lives, both in positive and negative ways hence every individual should digital awareness (Khanal et al., 2020; Joshi et al. 2021) for its their implications in appropriate activities. Despite making several tasks much more efficient and comfortable in everyday life, technological tools and gadgets have brought us a new 'eating disorder' that is growing day by day (Smahel et al., 2018). An individual's eating behavior can be defined as an interconnection of physiological, psychological, environmental, cultural, social, economic, and genetic factors associated with food preparation, eating time and frequency, quantity and quality, choice, and availability (Smahel et al., 2018). Technological devices and gadgets may have a good impact on making the best decisions about food choice and nutrition management in families on the one hand, and they may cause 'eating disorder' in several people on the other hand.

The pattern of food consumption represents the eating behavior of an individual. The selection of food quality is dependent on educational and financial status (Choudhury et al., 2019), and regular use of technology predicts ill-being after factoring out eating habits (Rosen et al., 2014). This study is concerned with postgraduate students as regular digital device users and their eating behavior. Their eating behavior can be observed in terms of efficiency, transparency, connections, and sustainable practices as the four areas of ICT in the food consumption system (Svenfelt \& Zapico, 2016). Although e-learning may play a key role in fighting hunger (ITU, 2009), intuitive eating can affect one's body mass index and psychological health (Dyke \& Drinkwater, 2013). The use of digital gadgets during eating may have an impact on one's health. It may be generally agreed that healthy food is essential to physical and mental health (Connell et al., 2005). A decrease in food intake can be a risk factor for mortality (Hiesmayr et al., 2009). However, ICT may help individuals choose a balanced diet (Lindsay et al., 2008) and organic food items (Bertoni et al., 2020). Therefore, if used purposefully and effectively, ICT can positively impact the consumption of fruits and vegetables (Dube et al., 2020). Nonetheless, Internet addiction can be harmful to a balanced diet and a healthy lifestyle (Kamran et al., 2018).

The utilization of new technological gadgets has influenced food consumption (Aleksejeva, 2014). A growth in fast food habits has adverse effects on personal health (AlSaad, 2016), and such practices are negatively correlated with the use of technology (Chowdhury et al., 2018). Research findings show that Internet users have unfortunate eating habits (Kim et al., 2010), have negative impacts on academic performance (Dutt et al., 2016) and contribute on mental health (Joshi, Singh \& Neupane, 2021). It has been found that the TV watching habits of individuals have a negative impact on food intake (Mathur \& Stevenson, 2015), leading to unhealthy eating habits (Harris \& Bargh, 2009) and fruit eating habits (Costa et al., 2012). Supportive policies are an effective way to improve diets among computer and laptop users (Kristo et al., 2019).

Some studies have demonstrated that the use of mobile phones during eating is positively associated with disordered eating (Hefner et al., 2016; Hussien et al., 2016). Other studies have shown that mobile applications are effective for awareness, choice, and 
consumption of healthy food (Gilliland et al., 2015). An individual's habit of using a phone may influence his or her eating behavior (Teo et al., 2018). In some studies, it was reported that eating behavior was highly correlated with the TV watching habits of children and adults (Harris \& Bargh, 2009). Children's food consumption behaviors were associated with the use of TV (Busse \& Diaz, 2016). Studies also show that digital resources have an essential role in food security and nutrition management (ITU, 2009). Therefore, past studies have shown that the use of digital devices may have both positive and negative effects on food consumption, causing 'healthy food habits' or resulting in 'eating disorders.'

The abovementioned studies show that the food consumption habits of an individual are affected by a variety of things. However, the use of digital devices is one of them. Previous studies focused on the effect of the use of TV and computers on eating habits. However, there are not adequate publications or literature that address the impact of using digital technologies, such as smartphones, computers, and TVs, on postgraduate students' eating behaviors in general and in the Nepalese context in particular. Therefore, this study aimed to examine the impact of using digital devices on postgraduate students' food consumption habits in Nepal. The study's parameters or variables were-device use time, preferred time, sitting position, the distance between digital tools, and the frequency of using digital devices and their impact on food consumption. Additionally, the research was carried out among digitally literate, highly educated, and job holders (financially sound) in the Nepalese context. Hence, the effect of digital devices on food consumption is the primary concern of this study.

\subsection{Literature Review}

Digital technology has been one of the contested issues in the modern age, though it has facilitated human communication to become part and parcel of modern people. Human dependency on generating, sharing, or searching for health information, communicating with other patients or healthcare professionals, or delivering health-related information through digital technologies can have different consequences. Smahel et al. (2018) researched digital technology with behaviors and disorders. The objective was to examine the impact of using digital technology on eating behaviors and disorders. The findings uncovered a broader insight into the effect of digital technology on eating behaviors and disorders based on the gratification theory (Katz et al., 1973), the technology acceptance model (Davis, 1989), displacement theory (Vandewater et al., 2004), and the major recommendations of the World Health Organization (1948). A qualitative study with an online assessment questionnaire adapted to users' assessment of online information and social networking sites (Adams, 2010; Eysenbach, 2008). The findings show that exposure to the media influences one toward body dissatisfaction (Cohen \& Blaszczynski, 2015). Exposure to appearance-focused online content and interactions can promote body dissatisfaction and disordered eating, whereas individuallevel factors such as gender can account as mediators/moderators of this effect (Holland \& Tiggemann, 2016; Perloff, 2014; Prieler \& Choi, 2014; Rodgers et al., 2016). The findings indicated that these emerging ICT and their uses may influence users' body image and eating behavior, prompting disordered eating.

Alcântara et al. (2019) studied scientific literature on digital technologies to promote healthy eating habits in teenagers. The study employed literature review-based analysis with a 
model called Preferred Reporting Items for Systematic Review and Meta-Analyses (PRISMA). They studied eight sample articles published in English and Spanish from January to March 2018. They analyzed information from the collected literature to conceptualize the major ideas of concerns and questions related to the study (Alcântara et al., 2019). The results indicated that among the studies included, three were digital games, two web-based nutrition interventions, two utilized web projects to prevent obesity, and one was nourishing counseling using multimedia (Alcântara et al., 2019). They demonstrated how digital innovation encounters and affects information to improve the conduct of participants in smart dieting propensities. Alcântara et al. (2019) further expressed those technological advancements with digital applications and devices are creative tools for adolescents with both being utilized for good purposes, such as education and self-awareness to promote healthy dieting, or they may intervene in a negative way by taking away concentration during eating, prompting disordered dieting.

Moduli (2015) studied the impact of technological addiction on the health and lifestyle of college students. The study examined the use of different tech devices by youths and how they spent their time with the gadgets and those devices impacted their mental health and lifestyle. The tool employed was a structured questionnaire, unstructured interviews, and observation to collect primary data from 150 respondents of NIT, Rourkela (Moduli, 2015). Findings indicated that most young respondents spend a large amount of their time on their tech gadgets and their services (Moduli, 2015). College students seemed to be pleasure-driven rather than necessity-driven by their addiction to tech gadgets (Moduli, 2015). Moduli (2015) argued that addiction to tech devices has many negative impacts on the aspects relating to the respondents' mental health and has become a causal factor in the change of lifestyle of youths in the modern age.

Lewis and Burton-Freeman (2010) studied the challenges faced in personalized nutrition and health. The aim of the study was to develop strategies to overcome challenges using innovations in food and information technology, and to characterize and organize a short-and long-haul research plan for the exploration stage. The workshop, entitled "The Role of Innovation and Technology in Meeting Individual Nutritional Needs," held in Washington, DC, September 25, 2008, was co-organized by the National Center for Food Safety and Technology (NCFST) and the FDA (Lewis \& Burton-Freeman, 2010). The workshop convened with leading regulators and nutrition, genetic, medical, toxicological, behavioral, and consumer experts. The workshop included experts' presentations and in-depth discussions with the participants who were randomly assigned to 4 groups ( $n=10-14$ per group) to identify critical research needs in genomics, behavior, food technology, and information technology (Lewis \& Burton-Freeman, 2010). Lewis and Burton-Freeman (2010) stated the study results that the workshop participants could identify the gaps, determine intersections, and new opportunities for delivering individualized food-based solutions that would be more accessible, affordable, and convenient (Lewis \& Burton-Freeman, 2010). The examination plan was created inside a framework of giving information and direction to the food and related ventures, supporting the procedure for well-being-related cases, and building consumer trust in information and food-wellbeing data. They emphasized pathways to using the US Dietary Guidelines for Americans and other open approaches, which mirrors the 
dedication of the network, government, food industry, well-being associations, and the scholarly world to improving well-being ((Lewis \& Burton-Freeman, 2010). The review of a few pieces of literature demonstrated the role of digital technologies in the improvement of healthy eating habits and food security. The explanation of the effect of digital devices on food consumption is supported by a theoretical framework, which has been discussed in the next section.

\subsection{Theoretical Framework}

We constructed a theoretical framework to facilitate the research method, analysis, and interpretation of the data. The frame demonstrates how technology can have multiple impacts on an individual's eating habits (Figure 1).

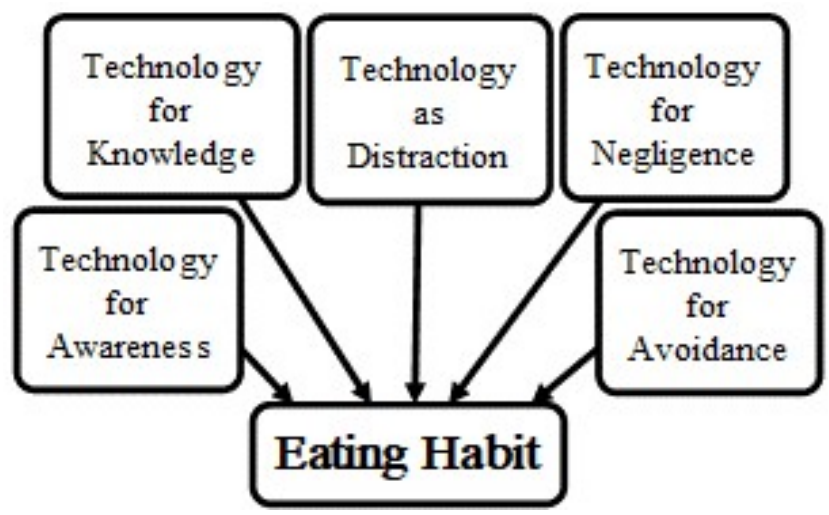

Figure 1. A theoretical framework for the study

Modern technological tools, such as digital devices, have changed people's lifestyles regarding awareness, knowledge, connectivity, and choices available for daily life activities from home to the office and other workplaces. These handheld devices have offered users promises to assess their dietary intake and make them aware of their nutritional values (Atienza et al., 2008). Nowadays, people use smartphones to learn about diet, nutrition, body mass index, and other personal and family health-related knowledge to practice healthy behaviors, such as eating (Coughlin et al., 2016). Research studies have reported that digital technology has not only offered many advantages in making healthy food choices and habits, but also brought us problems with eating and drinking habits by increasing food consumption due to lack of attention to eating and disrupting the "commensal aspect of drinking" (Spence et al., 2019, p. 1). Scholars have also claimed that, according to the displacement theory of digital devices, the excessive use of electronic gadgets has caused people's negligence of other essential activities, such as playing and eating together, and spending time on other important social activities. The lack of such activities and less movement due to the displacement of active behaviors and eating more often have resulted in obesity among children and young adults (Smahel et al., 2018). The outcome of excessive use or addiction to digital devices leads to frustration, anxiety, and depression. Then, people overuse the Internet on their devices "to avoid negative emotions, such as anxiety and depression" (Hoge, Bickham, \& Cantor, 2017, p. 77). We applied these five domains to construct a theoretical framework to observe how digital technology may influence postgraduate students' dietary practices in Nepal (Figure 1).

\section{RESEARCH METHODOLOGY}


This cross-sectional survey design was adopted among M Phil scholars of Nepal Open University (NOU) through an online survey. NOU is the first open university in Nepal, established in 2016 AD. Learning management system (LMS) for course management and communication tools such as BigBlueBotton, Skype for Business, and Microsoft Teams for virtual classes are significant attractions and adopted technologies in universities. Additionally, there is a provision and practice of three face-to-face contact sections each semester. Hence, all participants in the research had at least one digital device and were digitally literate.

During the research period, the total number of MPhil scholars was 469, which was assumed to be the total population. The self-constructed tool on Google Form was sent to all scholars for data collection, of which 320 (68.23\%) responded from Jan. 2019 to Sept. 2019. For the sample size calculation, an online calculator "select statistical services" was used which assumed $\mathrm{p}=50 \%$ because no prior research was conducted in the country. By the calculation, the sample size determined was 212 , and by adding $20 \%$ non-response, the final sample size obtained was 255, which was sufficient for this study (Select Statistical Services LTD, 2019). The email addresses and contact details of all scholars were taken from the administration of NOU, and the tool (detail of the variables in the tools are presented in Figure 2) was sent to all selected scholars and requested them to fill out the form. A onemonth reminder was given through email as well as a telephone call by the researcher.

\subsection{Definition of Variables}

The effect on the quantity of consumed food is an outcome variable, whereas gender, age, job types, availability of digital devices such as mobile phones, laptops, computers, and $\mathrm{TV}$, years of using digital devices, time of using digital devices, distance from the use of digital devices, and sitting position during the use of digital devices were taken as confounding variables. Gender was categorized as male (85.94\%) and female (14.06\%). Age was categorized as less than or equal to 36 years $(50.62 \%)$ and more than 36 years $(49.38 \%)$. Job types were separated into teaching $(27.50 \%)$ and non-teaching $(72.50 \%)$ professions. A detailed description of the variables is given in Figure 2. 


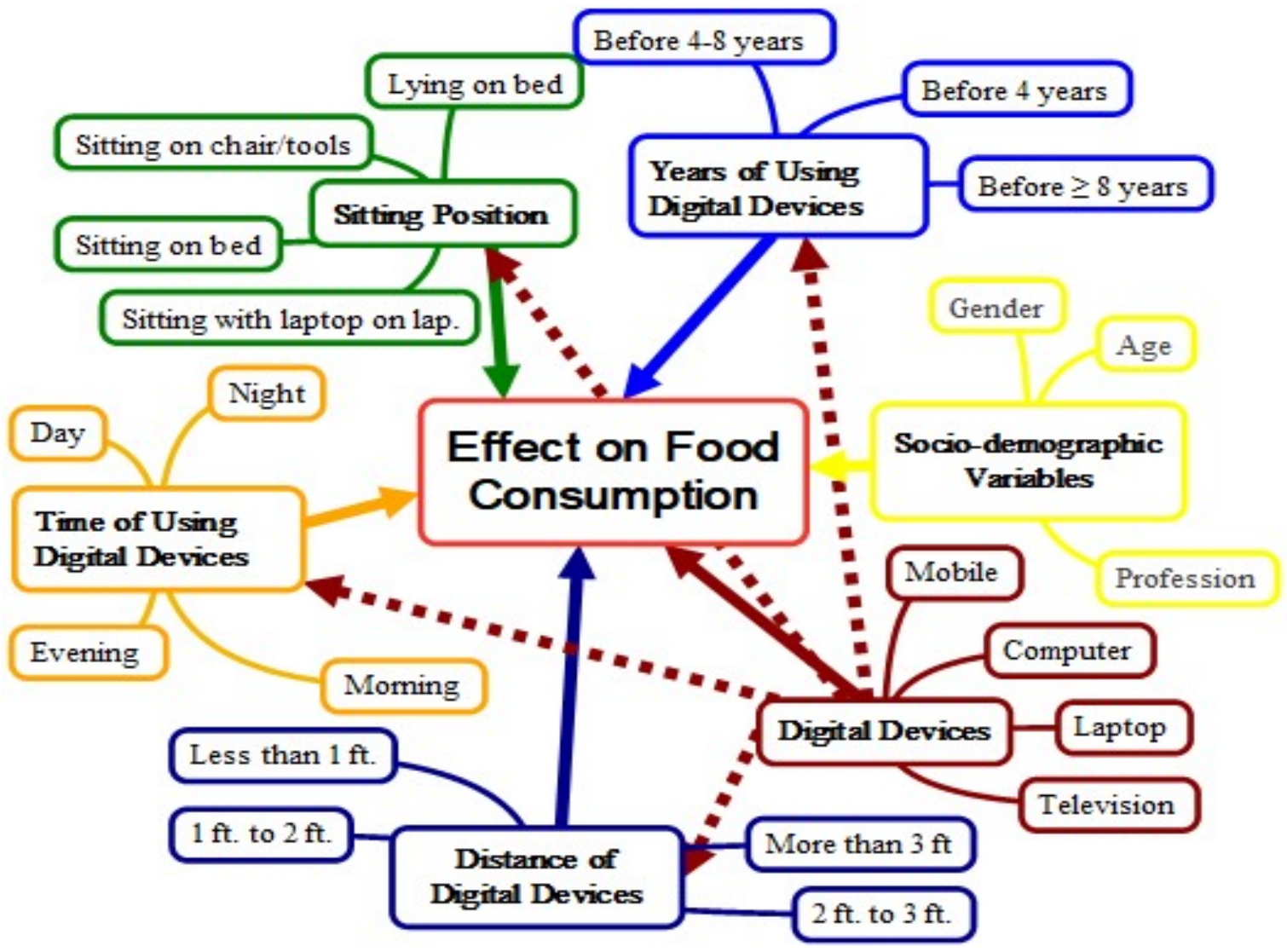

Figure 2. Description of variables for the study of the effect of digital devices on food consumption

\subsection{Statistical Analysis}

Descriptive and inferential statistics were used for data analysis. Frequency and percentage were used under descriptive statistics. The chi-square test was adopted under inferential statistics to calculate the association between the use of digital devices and the quantity of food consumed. Additionally, binary logistic regression was calculated to find the affecting factors on food consumption.

\section{Results}

Changes in food consumption by the use of digital devices

Table 1. Digital devises ownership and effect on the quantity of food consumed $(n=320)$.

\begin{tabular}{llllll}
\hline \multirow{2}{*}{$\begin{array}{l}\text { Digital } \\
\text { Device }\end{array}$} & $\begin{array}{l}\text { Changes in the quantity of food consumption since using digital } \\
\text { tools }\end{array}$ & $\begin{array}{l}\text { No effect in food } \\
\text { consumption }\end{array}$ & Eating little & $\begin{array}{l}\text { Not } \\
\text { interested } \\
\text { eating }\end{array}$ & $\begin{array}{l}\text { Eating } \\
\text { more }\end{array}$ \\
\hline Mobile & $194(60.25 \%)$ & $51(15.94 \%)$ & $62(19.38 \%)$ & $13(4.06 \%)$ & $320(100 \%)$ \\
Laptop & $192(60.95 \%)$ & $50(15.87 \%)$ & $61(19.67 \%)$ & $12(3.81 \%)$ & $315(100 \%)$ \\
Computer & $121(59.61 \%)$ & $33(16.25 \%)$ & $41(20.20 \%)$ & $8(3.94 \%)$ & $203(100 \%)$ \\
TV & $171(60.42 \%)$ & $45(15.90 \%)$ & $56(19.79 \%)$ & $11(3.89 \%)$ & $283(100 \%)$ \\
\hline
\end{tabular}


Table 1 shows that all participants have mobile phones; almost all of them have a laptop (98.44\%) and a TV (88.44\%) because all of them are students of NOU who were taking a virtual class, which is compulsory for all. Around two-thirds of them have computer $(63.44 \%)$ facilities. The sample was taken from students who were used to with different digital devices and were frequent users, so all of them had at least one device. The results show that around two-thirds of respondents have no effect on food consumption through the use of mobile phones, laptops, computers, and TV, whereas about one-third have an impact on food consumption (Table 1).

Socio-demographic characteristics and habits of food consumption

Table 2. Quantity of food consumption among digital device users by socio-demographic characteristics $(\mathbf{n}=\mathbf{2 3 0})$

\begin{tabular}{|c|c|c|c|c|c|c|}
\hline \multirow{2}{*}{$\begin{array}{l}\text { Socio- } \\
\text { demographic } \\
\text { Characteristic } \\
\text { s }\end{array}$} & \multirow[t]{2}{*}{$\begin{array}{l}\text { Categorie } \\
\mathrm{S}\end{array}$} & \multicolumn{4}{|c|}{$\begin{array}{l}\text { Quantity of food consumption since using digital } \\
\text { tools }\end{array}$} & \multirow[t]{2}{*}{ Total } \\
\hline & & $\begin{array}{l}\text { No effect in } \\
\text { food } \\
\text { consumptio } \\
n\end{array}$ & $\begin{array}{l}\text { Eating } \\
\text { more }\end{array}$ & $\begin{array}{l}\text { Eating } \\
\text { little }\end{array}$ & $\begin{array}{l}\text { Not } \\
\text { interested } \\
\text { in eating }\end{array}$ & \\
\hline \multirow[t]{2}{*}{ Gender } & Male & $164(59.04 \%$ & $10(3.6 \%)$ & $47(16.92 \%$ & $54(19.44 \%$ & $275(85.94 \%$ \\
\hline & Female & $30(66.70 \%)$ & $3(6.66 \%)$ & $4(8.88 \%)$ & $8(17.76 \%)$ & $45(14.06 \%)$ \\
\hline \multirow[t]{2}{*}{ Age } & $\leq \quad 36$ & $93(57.41 \%)$ & $6(3.70 \%)$ & $28(17.28 \%$ & $35(21.60 \%$ & $162(50.62 \%$ \\
\hline & $\begin{array}{ll}> & 36 \\
\text { years } & \end{array}$ & $101(63.92 \%$ & $7(4.43 \%)$ & $23(14.56 \%$ & $27(17.09 \%$ & $158(49.38 \%$ \\
\hline \multirow[t]{2}{*}{ Profession } & $\begin{array}{l}\text { Non- } \\
\text { Teaching }\end{array}$ & $55(62.5 \%)$ & $3(3.41 \%)$ & $12(13.64 \%$ & $18(20.45 \%$ & $88(27.50 \%)$ \\
\hline & Teaching & $139(59.91 \%$ & $10(4.31 \%$ & $\begin{array}{l}39(16.81 \% \\
)\end{array}$ & $44(7.23 \%)$ & $\begin{array}{l}232(72.50 \% \\
)\end{array}$ \\
\hline
\end{tabular}

Table 2 shows that the number of female (14.06\%) and non-teaching professionals $(27.5 \%)$ are far fewer than their male and teaching professionals' counterparts. Even near to equal number of samples were found on the basis of age. Based on the socio-demographic variables, more than one-third of participants have an effect on food consumption, where that rate is very poor in eating more.

Quantity of food consumed by the duration of using digital devices and their association

Table 3. Change in the quantity of food consumed by the duration of using digital $\operatorname{devices}(\mathbf{n}=320)$

\begin{tabular}{|c|c|c|c|c|c|c|c|}
\hline \multirow[b]{2}{*}{$\begin{array}{l}\text { Digital } \\
\text { Devices }\end{array}$} & \multirow{2}{*}{$\begin{array}{l}\text { Duration of } \\
\text { use of } \\
\text { Digital } \\
\text { Devices (in } \\
\text { Years) }\end{array}$} & \multicolumn{4}{|c|}{$\begin{array}{l}\text { Changes in the quantity of food consumption } \\
\text { since using digital tools }\end{array}$} & \multirow[t]{2}{*}{ Total } & \multirow{2}{*}{$\begin{array}{l}\mathrm{p}- \\
\text { valu } \\
\mathrm{e}\end{array}$} \\
\hline & & $\begin{array}{l}\text { No effect in } \\
\text { food } \\
\text { consumptio } \\
n\end{array}$ & $\begin{array}{l}\text { Eating } \\
\text { little }\end{array}$ & $\begin{array}{l}\text { Not } \\
\text { intereste } \\
d \quad \text { in } \\
\text { eating }\end{array}$ & $\begin{array}{l}\text { Eating } \\
\text { more }\end{array}$ & & \\
\hline Mobile & $<4$ years & $10(45.5 \%)$ & $2(9.1 \%)$ & $\begin{array}{l}7(31.8 \% \\
)\end{array}$ & $\begin{array}{l}3(13.6 \\
\%)\end{array}$ & $22(6.9 \%)$ & $\begin{array}{l}0.01 \\
*\end{array}$ \\
\hline
\end{tabular}


International Research Journal of MMC (IRJMMC)

Vol. 2 Issue 4 (December, 2021)

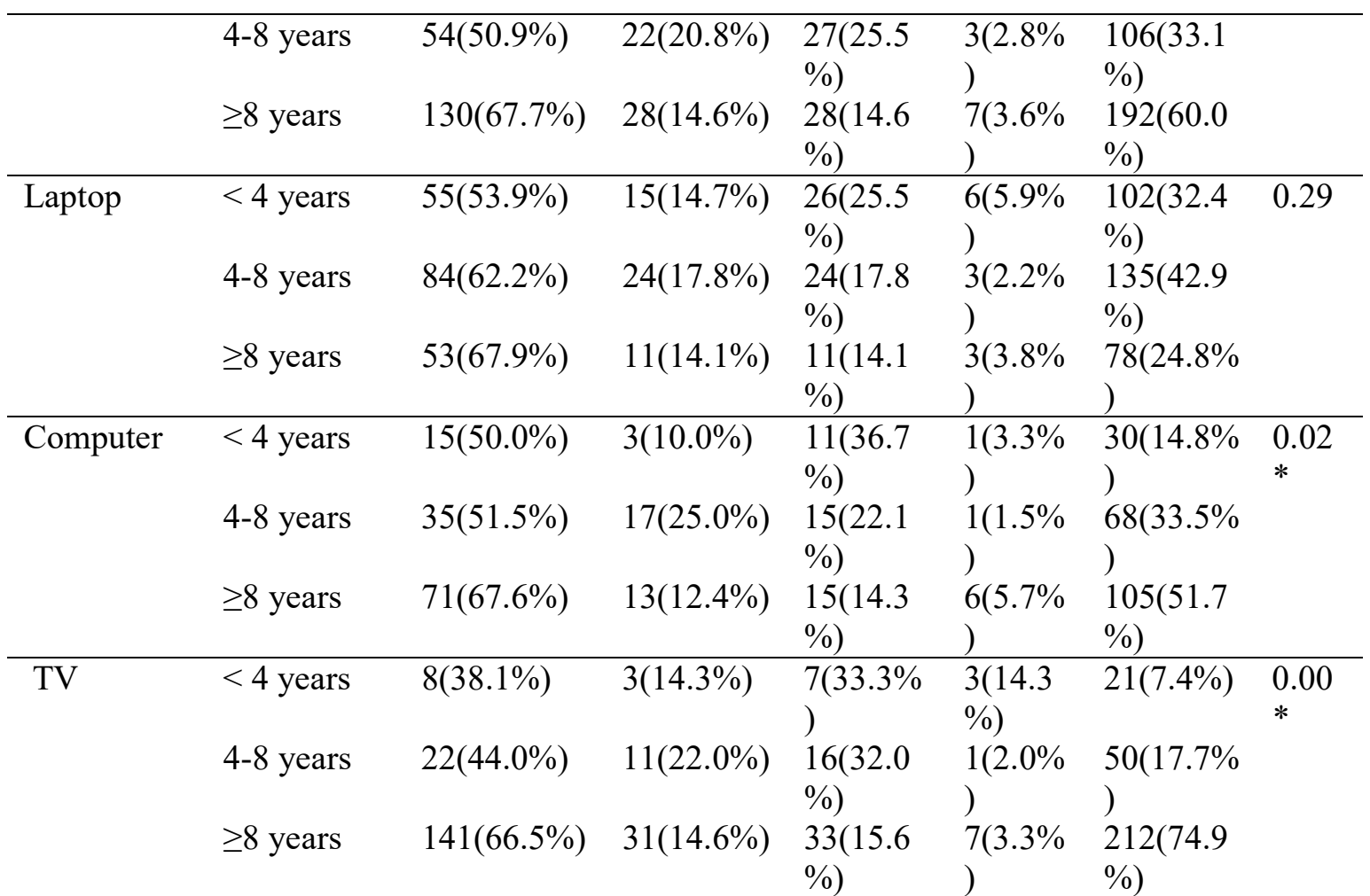

*association is significant at the 0.05 level (2-tailed).

Table 3 shows that around two-thirds of participants have been using mobile phones (67.7\%), laptops $(67.9 \%)$, computers $(67.6 \%)$, and TV $(66.5 \%)$ for more than eight years, which does not affect food consumption. The frequency of those participants using TV before four years (38.1\%) was found to be low in comparison to other categories of no effect on food consumption. The participants using a computer $(25 \%)$ and TV $(22 \%)$ have the highest frequency in comparison to others under the category of eating little, and that is found to be poor among mobile users before four years $(9.1 \%)$. The participants using a computer (36.7\%) and TV (33.3\%) before four years have a higher frequency of not being interested in eating related categories. The rate of responses to eating more is very poor in almost all items. The Chi-square result showed that significant associations were found between years of using mobile phones, computers, and TV with the change in the quantity of food consumed, where the result was insignificant in relation to years of using laptops at a $5 \%$ level of significance (Table 3).

Quantity of food consumed by the preferred time of using digital devices and their association

Table 4. Change in the quantity of food consumed by the preferred time of using digital devices $(n=320)$

\begin{tabular}{llllll}
\hline & $\begin{array}{l}\text { Preferre } \\
\text { d time }\end{array}$ & $\begin{array}{l}\text { Changes in the quantity of food consumption } \\
\text { since using digital tools }\end{array}$ & Total & p- \\
vigital & & $\begin{array}{l}\text { No effect in } \\
\text { food }\end{array}$ & Eating & Not & Eating \\
Devices & consumptio & & $\begin{array}{l}\text { interested } \\
\text { in eating }\end{array}$ & more & \\
\end{tabular}


$\mathrm{n}$

\begin{tabular}{|c|c|c|c|c|c|c|c|}
\hline \multirow{7}{*}{$\begin{array}{l}\text { Mobile } \\
(n=320)\end{array}$} & Day & $66(55.5 \%)$ & $20(16.8 \%$ & $18(15.1 \%$ & $5(4.2 \%$ & $119(37.2 \%$ & \multirow[t]{7}{*}{0.13} \\
\hline & & & & ) & ) & & \\
\hline & Evening & $63(65.6 \%)$ & $15(15.6 \%$ & $15(15.6 \%$ & $3(3.1 \%$ & $96(30.0 \%)$ & \\
\hline & & & ) & ) & ) & & \\
\hline & Morning & $27(52.9 \%)$ & $9(17.7 \%)$ & $13(25.5 \%$ & $2(3.9 \%$ & $51(15.9 \%)$ & \\
\hline & & & & ) & & & \\
\hline & Night & $38(70.4 \%)$ & $7(13.0 \%)$ & $6(11.1 \%)$ & $3(5.6 \%$ & $54(16.9 \%)$ & \\
\hline \multirow{6}{*}{$\begin{array}{c}\text { Laptop } \\
(n=315)\end{array}$} & Day & $59(72.8 \%)$ & $9(11.1 \%)$ & $11(13.6 \%$ & $2(2.5 \%$ & $81(25.3 \%)$ & \multirow{6}{*}{$\begin{array}{l}0.02 \\
*\end{array}$} \\
\hline & & & & ) & ） & & \\
\hline & Evening & $88(57.9 \%)$ & $25(16.5 \%$ & $33(21.7 \%$ & $6(4.0 \%$ & $152(48.3 \%$ & \\
\hline & & & ) & ) & ) & ) & \\
\hline & Morning & $8(39.1 \%)$ & $5(23.8 \%)$ & $7(33.3 \%)$ & $1(4.8 \%$ & $21(6.7 \%)$ & \\
\hline & Night & $37(60.7 \%)$ & $11(18.0 \%$ & $10(16.4 \%$ & $3(4.9 \%$ & $61(19.4 \%)$ & \\
\hline \multirow{5}{*}{$\begin{array}{l}\text { Compute } \\
r(n=203)\end{array}$} & Day & $64(58.7 \%)$ & $18(16.5 \%$ & $23(21.1 \%$ & $4(3.7 \%$ & $109(53.7 \%$ & \multirow[t]{5}{*}{0.62} \\
\hline & & & ) & ) & ） & ） & \\
\hline & Evening & $33(66.0 \%)$ & $8(16.0 \%)$ & $8(16.0 \%)$ & $1(2.0 \%$ & $50(24.6 \%)$ & \\
\hline & Morning & $6(54.6 \%)$ & $1(9.1 \%)$ & $4(36.4 \%)$ & $0(0.0 \%$ & $11(5.4 \%)$ & \\
\hline & Night & $18(54.6 \%)$ & $6(18.2 \%)$ & $6(18.2 \%)$ & $\begin{array}{l}3(9.1 \% \\
\end{array}$ & $33(16.3 \%)$ & \\
\hline \multirow{4}{*}{$\begin{array}{l}\text { TV } \\
(\mathrm{n}=283)\end{array}$} & Day & $6(54.6 \%)$ & $2(18.2 \%)$ & $2(18.2 \%)$ & $1(9.1 \%$ & $11(3.9 \%)$ & \multirow[t]{4}{*}{0.71} \\
\hline & Evening & $70(61.4 \%)$ & $17(14.9 \%$ & $25(21.9 \%$ & $2(1.8 \%$ & $114(40.3 \%$ & \\
\hline & Morning & $19(57.6 \%)$ & $6(18.2 \%)$ & $7(21.2 \%)$ & $1(3.0 \%$ & $33(11.7 \%)$ & \\
\hline & Night & $76(60.8 \%)$ & $\begin{array}{l}20(16.0 \% \\
)\end{array}$ & $\begin{array}{l}22(17.6 \% \\
)\end{array}$ & $\begin{array}{l}7(5.6 \% \\
)\end{array}$ & $125(44.2 \%$ & \\
\hline
\end{tabular}

*association is significant at the 0.05 level (2-tailed).

In Table 4, it can be shown that the majority of the participants were using mobile phones (37.19\%) and computers (53.69\%) at day time, laptops $(48.25 \%)$ in the evening, and TV (44.17\%) at night time compared to other options. Among laptop users of the morning time, the majority $(60.9 \%)$ of them have an effect on food consumption, whereas mobile users of the night time (70.37\%) and laptop users of the day time $(72.84 \%)$ have no effect on food consumption. Under the inferential statistics, the chi-square test showed a significant association between preferred time to use a laptop and the quantity of food consumed, where reverse results were measured by preferred time to use a mobile phone, computer, and TV with the quantity of food consumed (Table 4).

Quantity of food consumed by the position and distance during the use of digital devices and their association 
Table 5. Change in the quantity of food consumption by sitting position and distance of using digital tools $(\mathbf{n}=\mathbf{3 2 0})$

\begin{tabular}{|c|c|c|c|c|c|c|c|}
\hline \multirow[t]{2}{*}{$\begin{array}{l}\text { Variable } \\
\mathrm{s}\end{array}$} & \multirow[t]{2}{*}{ Options } & \multicolumn{4}{|c|}{$\begin{array}{l}\text { Change of the amount of food consumption since } \\
\text { using digital tools }\end{array}$} & \multirow[t]{2}{*}{ Total } & \multirow[t]{2}{*}{$\begin{array}{l}\mathrm{p}- \\
\text { value }\end{array}$} \\
\hline & & $\begin{array}{l}\text { No effect in } \\
\text { food } \\
\text { consumptio } \\
n\end{array}$ & $\begin{array}{l}\text { Eating } \\
\text { little }\end{array}$ & $\begin{array}{l}\text { Not } \\
\text { interested } \\
\text { in eating }\end{array}$ & $\begin{array}{l}\text { Eating } \\
\text { more }\end{array}$ & & \\
\hline \multirow[t]{5}{*}{ Position } & $\begin{array}{l}\text { Laying } \\
\text { on bed }\end{array}$ & $16(66.7 \%)$ & $3(12.5 \%)$ & $4(16.7 \%)$ & $1(4.2 \%)$ & $24(7.5 \%)$ & \multirow[t]{5}{*}{$\begin{array}{l}0.04 \\
*\end{array}$} \\
\hline & $\begin{array}{l}\text { Sitting } \\
\text { on bed }\end{array}$ & $32(50.8 \%)$ & $15(23.8 \%$ & $14(22.2 \%$ & $2(3.2 \%)$ & $63(19.7 \%)$ & \\
\hline & Sitting & $130(65.7 \%)$ & $28(14.1 \%$ & $32(16.2 \%$ & $8(4.0 \%)$ & $198(61.9 \%$ & \\
\hline & $\begin{array}{l}\text { on } \\
\text { chair/too } \\
1\end{array}$ & & ) & ) & & ) & \\
\hline & $\begin{array}{l}\text { Sitting } \\
\text { with a } \\
\text { laptop on } \\
\text { Lap }\end{array}$ & $16(45.7 \%)$ & $5(14.3 \%)$ & $\begin{array}{l}12(34.3 \% \\
)\end{array}$ & $2(5.7 \%)$ & $35(10.9 \%)$ & \\
\hline \multirow[t]{5}{*}{ Distance } & $<1 \mathrm{ft}$. & $45(54.9 \%)$ & $\begin{array}{l}13(15.9 \% \\
)\end{array}$ & $19(23.2 \%$ & $5(6.1 \%)$ & $82(25.6 \%)$ & \multirow[t]{4}{*}{0.55} \\
\hline & $1-2 \mathrm{ft}$. & $120(62.8 \%)$ & $32(16.6 \%$ & $34(17.8 \%$ & $5(2.6 \%)$ & $191(59.7 \%$ & \\
\hline & $2-3 \mathrm{ft}$. & $25(64.1 \%)$ & $4(10.3 \%)$ & $8(20.5 \%)$ & $2(5.1 \%)$ & $39(12.2 \%)$ & \\
\hline & $\geq 3 \mathrm{ft}$ & $4(50.0 \%)$ & $2(25.0 \%)$ & $1(12.5 \%)$ & $1(12.5 \%$ & $8(2.5 \%)$ & \\
\hline & Total & $194(60.2 \%)$ & $\begin{array}{l}51(15.9 \% \\
)\end{array}$ & $\begin{array}{l}62(19.4 \% \\
)\end{array}$ & $\begin{array}{l}13(4.1 \% \\
) \%\end{array}$ & $320(100 \%)$ & \\
\hline
\end{tabular}

*association is significant at the 0.05 level (2-tailed).

Table 5 showed that the majority of the participants were using digital devices by sitting on chairs/tools (61.88\%) and at a distance of 1-2 feet (59.69\%). Those using digital devices by sitting with a laptop on their lap have more effect on eating food $(56.29 \%)$, whereas another option has no impact on food consumption. The Chi-square results showed a significant association with the sitting position during the use of digital devices. The quantity of food consumed and an inverse relationship were found with the distance of digital tools (Table 5).

A summary of the data in the comparison of different variables and separate digital devices with the effect of food consumption is given in Figure 3 and Figure 4. It can be seen that the majority of the participants were using mobile phones $(37.19 \%)$ and computers $(53.69 \%)$ at day time, laptops $(48.25 \%)$ in the evening, and TV $(44.17 \%)$ at night time compared to other options. Among laptop users of the morning time, the majority $(60.9 \%)$ of them have an effect on food consumption, whereas mobile users of the night time $(70.37 \%)$ and laptop users of the day time (72.84\%) have no effect on food consumption. Under the inferential statistics, the chi-square test showed a significant association between preferred 
time to use a laptop and the quantity of food consumed, where reverse results were measured by preferred time to use a mobile phone, computer, and TV with the quantity of food consumed (Figure 4).

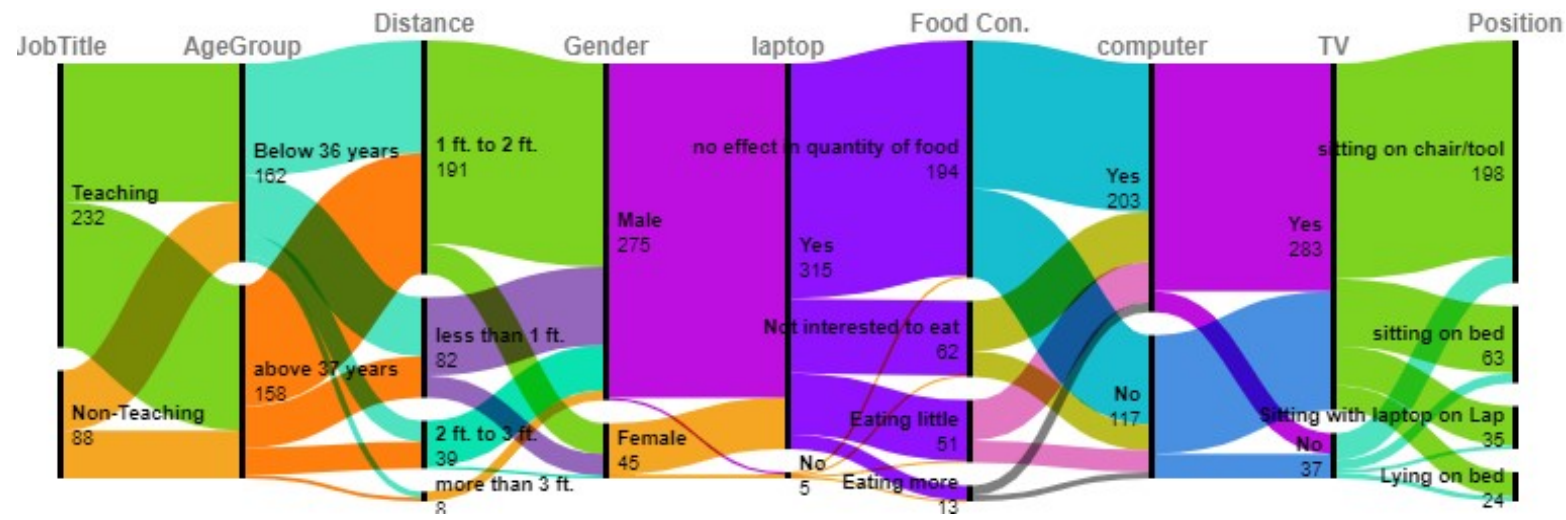

Figure 3. Detail of socio-demographic and ICT related information with food consumption

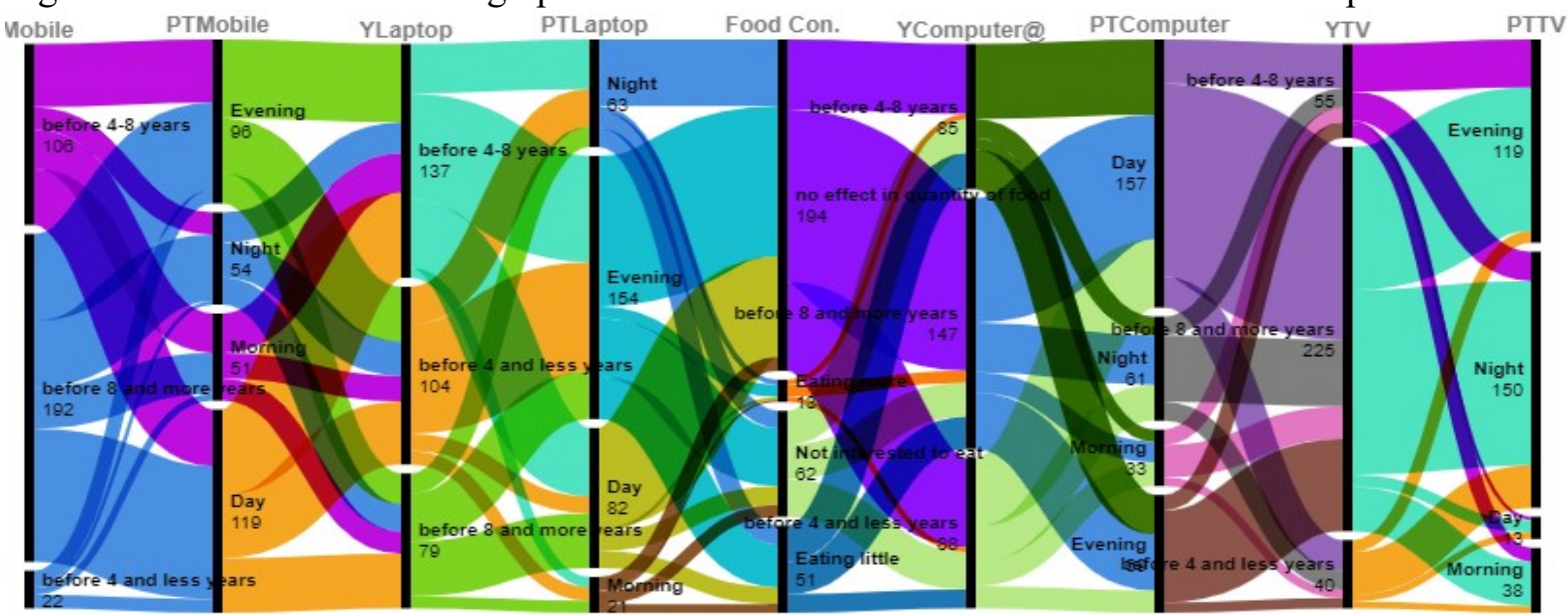

Figure 4. Detail of pattern and time of using digital devices with food consumption

A binary logistic regression model was applied by assuming two categories. The first one was 'no effect on food consumption' and the second was 'effect on food consumption' by merging eating little, not interested in eating and eating more as one category (Table 6). The logistic regression model was administered to assess the impact of different sociodemographic characteristics on the effect on food consumption. The model consists of seventeen independent factors (gender, age, job type, years of using digital devices, preferred time of using digital devices, sitting position and distance of digital devices during their use, which digital devices indicate mobile, laptop, computer, and TV). The full model with all predictors was statistically significant, $\mathrm{p}<0.05$, indicating that the model was able to distinguish an effect on food consumption. The model as a whole explained between $21.4 \%$ (Cox and Snell R square) and 28.81\% (Nagelkerke R squared) of the variance in effect on food consumption and correctly classified $71 \%$ of cases. As shown in Figure 4 and Table 6 , only three independent variables remained statistically significant contributions to the model.

Therefore, the strongest predictors of reporting on the effect on food consumption are digital devices used by respondents through lying on bed, sitting on bed, and sitting with a laptop on their lap. 
Table 6. Binary logistic regression analysis of the effect on food consumption based on socio-demographic characteristics

\begin{tabular}{|c|c|c|c|c|c|c|c|}
\hline & B & $\begin{array}{l}\mathrm{Si} \\
\mathrm{g} .\end{array}$ & $\begin{array}{l}\text { Odds } \\
\text { Ratio } \\
(95 \% \mathrm{CI})\end{array}$ & & $\mathrm{B}$ & Sig. & $\begin{array}{l}\text { Odds Ratio } \\
(95 \% \mathrm{CI})\end{array}$ \\
\hline Age & $\begin{array}{l}- \\
.06\end{array}$ & $\begin{array}{l}0 . \\
07\end{array}$ & $\begin{array}{l}0.95(0.89- \\
1.01)\end{array}$ & Use laptop at day & & $\begin{array}{l}0.2 \\
4\end{array}$ & Reference \\
\hline Job Type & - & $\begin{array}{l}0 . \\
99\end{array}$ & $\begin{array}{l}0.99(0.41- \\
2.42)\end{array}$ & $\begin{array}{l}\text { Use the laptop in } \\
\text { the evening }\end{array}$ & -.79 & $\begin{array}{l}0.2 \\
2\end{array}$ & $\begin{array}{l}0.45(0.13- \\
1.61)\end{array}$ \\
\hline Female & & 1 & Reference & $\begin{array}{l}\text { Use the laptop in } \\
\text { the morning }\end{array}$ & .12 & $\begin{array}{l}0.8 \\
2\end{array}$ & $\begin{array}{l}1.13(0.41- \\
3.16)\end{array}$ \\
\hline Male & .97 & $\begin{array}{l}0 . \\
11\end{array}$ & $\begin{array}{l}2.65(0.81- \\
8.71)\end{array}$ & $\begin{array}{l}\text { Use laptop at } \\
\text { night }\end{array}$ & .50 & $\begin{array}{l}0.5 \\
4\end{array}$ & $\begin{array}{l}1.65(0.34- \\
8.07)\end{array}$ \\
\hline $\begin{array}{l}\text { Use mobile by }<4 \\
\text { years. }\end{array}$ & & $\begin{array}{l}0 . \\
92\end{array}$ & Reference & $\begin{array}{l}\text { Use a computer at } \\
\text { day }\end{array}$ & & $\begin{array}{l}0.5 \\
9\end{array}$ & Reference \\
\hline $\begin{array}{l}\text { Use mobile by } 4-8 \\
\text { years }\end{array}$ & .27 & $\begin{array}{l}0 . \\
81\end{array}$ & $\begin{array}{l}1.31(0.15- \\
11.28)\end{array}$ & $\begin{array}{l}\text { Use a computer at } \\
\text { evening }\end{array}$ & .00 & $\begin{array}{l}0.9 \\
9\end{array}$ & $\begin{array}{l}1.00(0.33- \\
3.05)\end{array}$ \\
\hline $\begin{array}{l}\text { Use mobile by } \geq 8 \\
\text { years }\end{array}$ & .20 & $\begin{array}{l}0 . \\
70\end{array}$ & $\begin{array}{l}1.22(0.44- \\
3.38)\end{array}$ & $\begin{array}{l}\text { Use a computer at } \\
\text { morning }\end{array}$ & -.54 & $\begin{array}{l}0.3 \\
8\end{array}$ & $\begin{array}{l}0.58(0.17- \\
1.95)\end{array}$ \\
\hline $\begin{array}{l}\text { Use a laptop by }<4 \\
\text { years. }\end{array}$ & & $\begin{array}{l}0 . \\
63\end{array}$ & Reference & $\begin{array}{l}\text { Use a computer at } \\
\text { night }\end{array}$ & .29 & $\begin{array}{l}0.7 \\
4\end{array}$ & $\begin{array}{l}1.33(0.25- \\
7.11)\end{array}$ \\
\hline $\begin{array}{l}\text { Use laptop by } 4-8 \\
\text { years }\end{array}$ & - & $\begin{array}{l}0 . \\
44\end{array}$ & $\begin{array}{l}0.57(0.13- \\
2.38)\end{array}$ & Use TV on day & & $\begin{array}{l}0.6 \\
9\end{array}$ & Reference \\
\hline $\begin{array}{l}\text { Use laptop by } \geq 8 \\
\text { years }\end{array}$ & - & $\begin{array}{l}0 . \\
95\end{array}$ & $\begin{array}{l}0.97(0.51- \\
2.67)\end{array}$ & $\begin{array}{l}\text { Use TV in the } \\
\text { evening }\end{array}$ & .50 & $\begin{array}{l}0.7 \\
5\end{array}$ & $\begin{array}{l}1.65(0.08- \\
33.90)\end{array}$ \\
\hline $\begin{array}{l}\text { Use the computer by } \\
<4 \text { years. }\end{array}$ & & $\begin{array}{l}0 . \\
48\end{array}$ & Reference & $\begin{array}{l}\text { Use TV in the } \\
\text { morning }\end{array}$ & -.18 & $\begin{array}{l}0.6 \\
6\end{array}$ & $\begin{array}{l}0.83(0.37- \\
1.86)\end{array}$ \\
\hline $\begin{array}{l}\text { Use computer by } 4-8 \\
\text { years }\end{array}$ & .73 & $\begin{array}{l}0 . \\
39\end{array}$ & $\begin{array}{l}2.07(0.39- \\
10.94)\end{array}$ & Use TV at night & .50 & $\begin{array}{l}0.3 \\
9\end{array}$ & $\begin{array}{l}1.65(0.52- \\
5.20)\end{array}$ \\
\hline $\begin{array}{l}\text { Use computer by } \geq 8 \\
\text { years }\end{array}$ & .59 & $\begin{array}{l}0 . \\
23\end{array}$ & $\begin{array}{l}1.80(0.69- \\
4.70)\end{array}$ & Laying on bed & & $\begin{array}{l}0.0 \\
1 *\end{array}$ & Reference \\
\hline Use TV by $<4$ years & & $\begin{array}{l}0 . \\
37\end{array}$ & Reference & Sitting on bed & $\begin{array}{l}- \\
2.5 \\
6\end{array}$ & $\begin{array}{l}0.0 \\
1 *\end{array}$ & $\begin{array}{l}0.08(0.01- \\
0.55)\end{array}$ \\
\hline Use TV by $4-8$ years & $\begin{array}{l}1.1 \\
4\end{array}$ & $\begin{array}{l}0 . \\
17\end{array}$ & $\begin{array}{l}3.11(0.61- \\
15.83)\end{array}$ & $\begin{array}{l}\text { Sitting on } \\
\text { chair/tool }\end{array}$ & -.68 & $\begin{array}{l}0.3 \\
0\end{array}$ & $\begin{array}{l}0.51(0.14- \\
1.82)\end{array}$ \\
\hline Use TV by $\geq 8$ years & $\begin{array}{l}- \\
.09\end{array}$ & $\begin{array}{l}0 . \\
88\end{array}$ & $\begin{array}{l}0.91(0.28- \\
2.94)\end{array}$ & $\begin{array}{l}\text { Sitting with laptop } \\
\text { on Lap }\end{array}$ & $\begin{array}{l}- \\
1.4 \\
9\end{array}$ & $\begin{array}{l}0.0 \\
1 *\end{array}$ & $\begin{array}{l}0.23(0.08- \\
0.66)\end{array}$ \\
\hline Use mobile at day & & $\begin{array}{l}0 . \\
19\end{array}$ & Reference & Distance $<1 \mathrm{ft}$. & & $\begin{array}{l}0.7 \\
5\end{array}$ & Reference \\
\hline $\begin{array}{l}\text { Use mobile in the } \\
\text { evening }\end{array}$ & .92 & $\begin{array}{l}0 . \\
10\end{array}$ & $\begin{array}{l}2.52(0.85- \\
7.48)\end{array}$ & Distance $1-2 \mathrm{ft}$. & .91 & $\begin{array}{l}0.4 \\
3\end{array}$ & $\begin{array}{l}2.46(0.27- \\
22.82)\end{array}$ \\
\hline $\begin{array}{l}\text { Use mobile in the } \\
\text { morning }\end{array}$ & .28 & $\begin{array}{l}0 . \\
64\end{array}$ & $\begin{array}{l}1.32(0.41- \\
4.26)\end{array}$ & Distance $2-3 \mathrm{ft}$. & -.4 & $\begin{array}{l}0.5 \\
5\end{array}$ & $\begin{array}{l}0.66(0.17- \\
2.57)\end{array}$ \\
\hline Use mobile at night & $\begin{array}{l}1.0 \\
7\end{array}$ & $\begin{array}{l}.1 \\
1\end{array}$ & $\begin{array}{l}2.91(0.80- \\
10.63)\end{array}$ & Distance $\geq 3 \mathrm{ft}$. & -.05 & $\begin{array}{l}0.9 \\
2\end{array}$ & $\begin{array}{l}0.96(0.41- \\
2.26)\end{array}$ \\
\hline
\end{tabular}




\section{RESULT AND DISCUSSION}

The majority of the participants had at least one digital device. It was because all the participants were students at the university who were taking an online class through a virtual platform. Around two-thirds of the respondents had no effect on food consumption while using digital devices regarding different socio-demographic characteristics. Around one-third of digital device users have a problem with food consumption. Even so, that rate is comparatively poor among teaching professionals. A majority of the research participants expressed that they had no effect on food consumption by using a mobile, laptop, computer, and TV. Even the frequency of using mobile phones and laptops seemed to affect the factors for the quantity of food consumed (Figure 3 and Figure 4). It may be because almost all of them have these types of devices and they are properly used in their regular activities. Before 4-8 years, computer and TV users did not have problems with eating.

Significant associations were found between the duration of using mobile phones, computers and TV with the quantity of eating food consumed, preferred time of using a laptop with the amount of eating food consumed and the sitting position during the use of digital devices with the quantity of eating food consumption. The relationship is insignificant in remaining cases. Watching food-related television programs had a significant effect on eating behaviors (Joyner, 2014). A significant effect was found between watching TV and food consumption (Chapman et al., 2014). These findings are found to be consistent with the idea that TV's engagingness can differentially affect food intake (Mathur \& Stevenson, 2015). The differences were significant for the frequency of food consumption in the Internet advertisement condition (Pettigrew et al., 2013). The use of mobile applications and microblogs were significantly and positively associated with reports of disordered eating (Dube et al., 2020). Watching food-related television programs had a significant effect on eating behaviors (Joyner, 2014).

\section{Policy Implications}

The Government of Nepal formed a High-Level Nutrition and Food Security Steering Committee (HLNFSSC) to develop plans and policies for nutrition and food security from the central to local governments. This body includes the seven ministries of the government and other stakeholders, including some donor agencies and non-government organizations in Nepal (National Nutrition and Food Security Secretariat, National Planning Commission, 2015). These initiatives resulted in a Multisector Nutrition Plan (MSNP) 2018-2022 commitment that drafted an MSNP-Framework integrating the efforts of the National Planning Commission, Ministry of Health and Population, Ministry of Education, Ministry of Federal Affairs and Local Development, Ministry of Urban Development, Federal Affairs and Local Development, Ministry of Agriculture Development, and Ministry of Women, Children, and Social Welfare (Government of Nepal, 2017). The framework focuses on improving access to nutrition-related services for people with targeted three broad outcomes: maternal health, children and adolescent nutritional services, access and equity, and related policies and plans. Most of the food-related problems and issues have been dealt with from the viewpoint of malnutrition, child growth and development, and food security by the government, non-government organizations, and international development partners and 
donors, such as the World Food Program and Feed the Future of the US Government Initiative, to name a few. However, there is not any provision of nutrition education, awareness, and services for average adults in general and a large number of higher education students in particular. The findings of the current study showed how the use of digital devices or technological tools might affect eating habits and nutrition balance in children, young people, and adults' bodies can harm physical growth and development and psychological and social well-being. This finding could have policy implications. The Government of Nepal and the National Planning Commission should update and broaden the policies related to food and nutrition to the changing context of the growing use of different electronic gadgets by students, negatively impacting their eating habits with imbalanced nutrition and mental and social problems.

\section{CONCLUSION}

The study found that all participants used at least one of the following digital devices: $\mathrm{TV}$, laptop, mobile, and computer. The results indicated that around one-third of respondents have an effect on food consumption by using digital tools; mobile phones, laptops, computers, and TV. Significant associations were found between mobile, computer, and TV duration with the quantity of food consumed. The preferred time for using a laptop and sitting position are significantly associated with the amount of food consumption. The sitting posture is the main predictor of determining the amount of food consumed. Since the study was limited to the MPhil level of only one university, sample size, and only one developing country, Nepal, further studies can be conducted on the general public, among different countries, and by taking several institutions. Also, the study is survey-based; hence, experimental research will be more accurate about the study content. However, this study's findings are very applicable and useful to all technology users, policymakers, health workers, and educators for the careful use of digital resources. Therefore, awareness of the consequences of using digital devices through the BCC program, social media, television, and radio should be implemented.

\section{REFERENCES}

Adams, S. A. (2010). Revisiting the online health information reliability debate in the wake of "web 2.0": An inter-disciplinary literature and website review. International Journal of Medical Informatics, 79(6), 391-400. https://doi.org/10.1016/j.ijmedinf.2010.01.006

Alcântara, C. M. D., Silva, A. N. S., Pinheiro, P. N. D. C., \& Queiroz, M. V. O. (2019). Digital technologies for promotion of healthy eating habits in teenagers. Revista brasileira de enfermagem, 72(2), 513-520. doi: http://dx.doi.org/10.1590/0034-7167-2018-0352

Aleksejeva, I. (2014). How do the new technologies in food production affect consumer choice? Regional Formation and Development Studies, 1(9), 6-13. https://doi.org/10.15181/rfds.v9i1.589

Al-saad, E. (2016). Causes and effects of fast food. International Journal of Scientific \& Technology Research, 5(4), 279-280.

Atienza, A., King, A. C., Oliveira, B. M., Ahn, D. K., \& Gardner, C. D. (2008). Using handheld computer technologies to improve dietary intake. American Journal of Preventive Medicine, 34(6), 514-518. DOI: https://doi.org/10.1016/j.amepre.2008.01.034

Bertoni, D., Curzi, D., Aletti, G., \& Olper, A. (2020). Estimating the effects of agrienvironmental measures using difference-in-difference coarsened exact matching. Food Policy, 90, 1-20. https://doi.org/10.1016/j.foodpol.2019.101790 
Busse, P., \& Diaz, R. (2016). What are the television viewing and eating habits of children in Peru? Global Health Promotion, 23(1), 50-60. https://doi.org/10.1177/1757975914547923

Chapman, C. D., Nilsson, V. C., Thune, H. A., Cedernaes, J., Greves, M. Le, Hogenkamp, P. S., Benedict, C., \& Schioth, H. B. (2014). Watching TV and food intake: The role of content. PLoS ONE, 9(7), 1-4. https://doi.org/10.1371/journal.pone.0100602

Choudhury, S., Headey, D. D., \& Masters, W. A. (2019). First foods : Diet quality among infants aged 6-23 months in 42 countries. Food Policy, 88, 1-11. https://doi.org/10.1016/j.foodpol.2019.101762

Chowdhury, R., Subho, R. H., Rahman, M., Islam, S., \& Chaki, D. (2018). The impact of fast food consumption on health: a study on university students of Bangladesh. 21st International Conference of Computer and Information Technology. https://doi.org/10.1109/ICCITECHN.2018.8631962

Cohen, R., \& Blaszczynski, A. (2015). Comparative effects of Facebook and conventional media on body image dissatisfaction. Journal of Eating Disorders, 3(1), 23. https://doi.org/10.1186/s40337-015-0061-3

Connell, C. L., Lofton, K. L., Yadrick, K., \& Rehner, T. A. (2005). Children's experiences of food insecurity can assist in understanding its effect on their well-being. Children's Experiences off Food Insecurity, 135, 1683-1690.

Costa, S. M. M., Horta, P. M., \& Santos, L. C. dos. (2012). Food advertising and television exposure: Influence on eating behavior and nutritional status of children and adolescents. Archivos Latinoamericanos de Nutricion, 6(1), 53-59.

Coughlin, S. S., Whitehead, M., Sheats, J. Q., Mastromonico, J., Hardy, D., \& Smith, S. A. (2015). Smartphone applications for promoting healthy diet and nutrition: A literature review. Jacobs Journal of Nutrition, 2(3), 021. Online accessed on August 3, 2020 from: https://www.ncbi.nlm.nih.gov/pmc/articles/PMC4725321/

Davis, F. D. (1989). Perceived usefulness, perceived ease of use, and user acceptance of information technology. MIS Quarterly, 13(3), 319e340. https://doi.org/10.2307/249008

Dube, L., Mcrae, C., Wu, Y., Ghosh, S., Allen, S., Ross, D., Ray, S., Joshi, P. K., Mcdermott, J., Jha, S., \& Moore, S. (2020). Impact of the eKutir ICT-enabled social enterprise and its distributed micro-entrepreneur strategy on fruit and vegetable consumption: A quasiexperimental study in rural and urban communities in Odisha, India. Food Policy, 90, 2 12. https://doi.org/10.1016/j.foodpol.2019.101787

Dutt, R. A., Manippady, B. B., Bangera, S., Paneerselvam, P., \& Gonsalves, J. (2016). Interplay of "rest," "internet," and "diet" and on academic performance-medical students' perspective. National Journal of Physiology, Pharmacy and Pharmacology, 6(6), 586-590. https://doi.org/10.5455/njppp.2016.6.0615429062016

Dyke, N. Van, \& Drinkwater, E. J. (2013). Relationships between intuitive eating and health indicators: literature review. Public Health Nutrition, 17(8), 1757-1766. https://doi.org/10.1017/S1368980013002139

Eysenbach, G. (2008). Medicine 2.0: Social networking, collaboration, participation, apomediation, and openness. Journal of Medical Internet Research, 10(3), e22. https://doi.org/10.2196/jmir.1030

Gilliland, J., Sadler, R., Clark, A., O’Connor, C., Milczarek, M., \& Doherty, S. (2015). Using a smartphone application to promote healthy dietary behaviours and local food consumption. BioMed Research International, 2015, 1-11. https://doi.org/10.1155/2015/841368 
Government of Nepal. (2017). Multi-sector nutrition plan-II (2018-2022). Singhdurbar, Kathmandu: National Planning Commission. http://nnfsp.gov.np/PublicationFiles/b8aae359-15ea-40c4-aa13-b1076efb251b.pdf

Harris, J. L., \& Bargh, J. a. (2009). The relationship between television viewing and unhealthy eating: implications for children and media interventions. Health Commun, 24(7), 660-673. https://doi.org/10.1080/10410230903242267.

Hefner, V., Dorros, S. M., Jourdain, N., Liu, C., Tortomasi, A., Greene, M. P., Brandom, C., Ellet, M., \& Bowles, N. (2016). Mobile exercising and tweeting the pounds away: The use of digital applications and microblogging and their association with disordered eating and compulsive exercise. Cogent Social Sciences, 6, 1-11. https://doi.org/10.1080/23311886.2016.1176304

Hiesmayr, M., Schindler, K., Pernicka, E., Schuh, C., Schoeniger-Hekele, A., Bauer, P., Laviano, A., Lovell, A. D., Mouhieddine, M., Schuetz, T., Schneider, S. M., Singer, P., Pichard, C., Howard, P., Jonkers, C., Grecu, I., Ljungqvist, O., Nutritionday, T., \& Team, A. (2009). Decreased food intake is a risk factor for mortality in hospitalised patients: The nutrition day survey 2006. Clinical Nutrition, 28, 484-491. https://doi.org/10.1016/j.clnu.2009.05.013

Hoge, E., Bickham, D., \& Cantor, J. (2017). Digital media, anxiety, and depression in children. PEDIATRICS, 140(2), e20161758. Accessed online on August 3, 2020 from: https://pediatrics.aappublications.org/content/pediatrics/140/Supplement 2/S76.full.pdf

Holland, G., \& Tiggemann, M. (2016). A systematic review of the impact of the use of social networking sites on body image and disordered eating outcomes. Body Image, 17, 100 110. https://doi.org/10.1016/j.bodyim.2016.02.008

Hussien, M. H., Miskon, M. I., Kamaruddin, A. F., \& Ishak, N. (2016). The impacts of modern technology on food. Nova Journal of Medical and Biological Sciences, 5(1), 16. https://doi.org/10.20286/nova-jmbs-050186

ITU. (2009). ICTs and Food Security. https://www.itu.int/dms pub/itut/oth/23/01/T230100000B0001PDFE.pdf

Joyner, M. (2014). The effect of watching food-related television on eating behaviors and cravings. University of Michigan.

Joshi, D. R., Neupane, U., \& Joshi, P. R. (2021). Synthesis review of digital frameworks and DEPSWALIC digital competency framework for teachers from basic to university level. Mathematics Teaching Research Journal, 13(2), 108-136. https://commons.hostos.cuny.edu/mtrj/wp-content/uploads/sites/30/2021/07/v13n2Synthesis-Review-of-Digital-Frameworks.pdf

Joshi, D. R., Singh, J. K., \& Neupane, U. (2021). Mental Health Problems and Patterns of Self-Care Associated with the Use of Digital Devices among University Students. European Journal of Mental Health, 16(2), 146-169. https://doi.org/10.5708/EJMH.16.2021.2.7

Kamran, H., Afreen, A., \& Ahmed, Z. (2018). Effect of internet addiction on dietary behavior and lifestyle characteristics among university students. Annals of King Edward Medical University, 24(S), 836-841. https://doi.org/10.21649/akemu.v24is.2518

Katz, E., Blumler, J. G., \& Gurevitch, M. (1973). Uses and gratifications research. Public Opinion Quarterly, 37(4), 509. https://doi.org/10.1086/268109

Khanal, B., Belbase, S., \& Joshi, D. R. (2021). Effect of Digital Awareness on Mathematics Achievements at School to University Levels in Nepal. Mathematics Teaching Research Journal, 12(4), 47-68. $\quad$ https://commons.hostos.cuny.edu/mtrj/wpcontent/uploads/sites/30/2021/01/v12n4-Effect-of-Digital-Awareness-on-MathematicsAchievements.pdf 
Kim, Y., Park, J. Y., Kim, S. B., Jung, I. K., Lim, Y. S., \& Kim, J. H. (2010). The effects of Internet addiction on the lifestyle and dietary behavior of Korean adolescents. Nutrition Research and Practice, 4(1), 51-57. https://doi.org/10.4162/nrp.2010.4.1.51

Kristo, A. S., Gültekin, B., Öztağ, M., Sikalidis, A. K., Waterlander, W. E., Jiang, Y., Nghiem, N., Eyles, H., Wilson, N., Cleghorn, C., Genç, M., Swinburn, B., Mhurchu, C. N., \& Blakely, T. (2019). The effect of food price changes on consumer purchases: a randomised experiment. The Lancet Public Health, 4(8), e394-e405. https://doi.org/10.1016/S2468-2667(19)30105-7

Lewis, K. D., \& Burton-Freeman, B. M. (2010). The role of innovation and technology in meeting individual nutritional needs. The Journal of nutrition, 140(2), 426S-436S.

Lindsay, S., Bellaby, P., Smith, S., \& Baker, R. (2008). Enabling healthy choices: Is ICT the highway to health improvement? Health: An Interdisciplinary Journal for the Social Study of Health, Illness and Medicine, 12(3), 313-331. https://doi.org/10.1177/1363459308090051

Mathur, U., \& Stevenson, R. J. (2015). Television and eating: Repetition enhances food intake. Frontiers in Psychology, 6, 1-8. https://doi.org/10.3389/fpsyg.2015.01657

Muduli, J. R. (2014). Addiction to technological gadgets and its impact on health and lifestyle: A study on college students (Masters dissertation). National Institute of Technology, Rourkela, India.

National Nutrition and Food Security Secretariat, National Planning Commission. (2015). Nepal nutrition and food security portal: Governance. Thapathali, Kathmandu: Central Bureau of Statistics. http://www.nnfsp.gov.np/Governance.aspx

Perloff, R. M. (2014). Social media effects on young women's body image concerns: Theoretical perspectives and an agenda for research. Sex Roles, 71(11-12), 363-377. https://doi.org/10.1007/s11199-014-0384-6

Pettigrew, S., Tarabashkina, L., Roberts, M., Quester, P., Chapman, K., \& Miller, C. (2013). The effects of television and Internet food advertising on parents and children. Public Health Nutrition, 16(12), 2205-2212. https://doi.org/10.1017/S1368980013001067

Prieler, M., \& Choi, J. (2014). Broadening the scope of social media effect research on body image concerns. Sex Roles, 71(11-12), 378-388. https://doi.org/10.1007/s11199-014$\underline{0406-4}$

Rodgers, R. F., Lowy, A. S., Halperin, D. M., \& Franko, D. L. (2016). A meta-analysis examining the influence of pro-eating disorder websites on body image and eating pathology. European Eating Disorders Review, 24(1), 3-8. https://doi.org/10.1002/erv.2390

Rosen, L. D., Lim, A. F., Felt, J., Carrier, L. M., Cheever, N. A., Lara-Ruiz, J. M., Mendoza, J. S., \& Rokkum, J. (2014). Media and technology use predicts ill-being among children, preteens and teenagers independent of the negative health impacts of exercise and eating habits. Computers in Human Behavior, 35, 364-375. https://doi.org/10.1016/j.chb.2014.01.036

Smahel, D., Machackova, H., Smahelova, M., Cevelicek, M., Almenara, C. A., \& Holubcikova, J. (2018). Digital technology, eating behaviors, and eating disorders. Cham, Switzerland: Spring. DOI: https://doi.org/10.1007/978-3-319-93221-7

Šmahel, D., Macháčková, H., Šmahelová, M., Čevelíček, M., Almenara, C. A., \& Holubčíková, J. (2018). Digital technology, eating behaviors, and eating disorders. Springer International Publishing.

Spence, C., Mancini, M., \& Huisman, G. (2019). Digital commensality: Eating and drinking in the company of technology. Frontiers in Psychology, 10. 2252. DOI: https://doi.org/10.3389/fpsyg.2019.02252 
Select Statistical Services LTD (2019). Population proportion-Sample size. Retrieved 10 May 2019 from https://select-statistics.co.uk/calculators/sample-size-calcu-lator-populationproportion/.

Svenfelt, A., \& Zapico, J. L. (2016). Sustainable food systems with ICT? 4th International Conference on ICT for Sustainability. Online accessd from: https://www.atlantispress.com/proceedings/ict4s-16/25860383

Teo, E., Goh, D., Vijayakumar, K. M., \& Liu, J. C. J. (2018). To message or browse? Exploring the impact of phone use patterns on male adolescents' consumption of palatable snacks. Frontiers in Psychology, 8, 1-7. https://doi.org/10.3389/fpsyg.2017.02298

Vandewater, E. A., Shim, M., \& Caplovitz, A. G. (2004). Linking obesity and activity level with children's television and video game use. Journal of Adolescence, 27(1), 71. https://doi.org/10.1016/j.adolescence.2003.10.003

World Health Organization. (1948) Constitution of the World Health Organization. Retrieved from http://www.who.int/governance/eb/who_constitution_en.pdf 